\title{
EFEKTIVITAS MODEL PEMBELAJARAN RESIK DALAM MENINGKATKAN KEMAMPUAN KONEKSI MATEMATIS SISWA KELAS XI MIA
}

\author{
N. W. D. Anggreni' I. N. Sukajaya, I. M. Ardana \\ Jurusan Matematika, FMIPA Universitas Pendidikan Ganesha \\ Singaraja, Indonesia \\ e-mail: \{niwayandesianggreni, ardanaimade, nyoman.sukajaya\}@undiksha.ac.id
}

\begin{abstract}
Abstrak
Penelitian ini bertujuan untuk mengetahui efektivitas model pembelajaran Resik dalam meningkatkan kemampuan koneksi matematis siswa kelas XI MIA SMA Negeri 1 Susut. Jenis penelitian ini adalah eksperimen semu dengan desain penelitian post-test only control group design. Populasi adalah siswa kelas XI MIA SMA Negeri 1 Susut tahun ajaran 2018/2019 sebanyak 132 siswa. Sampel penelitian ditentukan dengan teknik cluster random sampling, diperoleh sampel penelitian sebanyak 46 siswa. Data kemampuan koneksi matematis siswa dikumpulkan melalui tes uraian yang diberikan kepada siswa di akhir penelitian. Analisis data menggunakan uji-t satu ekor yaitu ekor kanan, dengan taraf signifikansi $5 \%$. Hasil analisis data menunjukkan bahwa nilai $t_{\text {hitung }}$ $=3,91147$ lebih dari $t_{\text {tabel }}=1,68023$. Hal ini berarti kemampuan koneksi matematis siswa yang mengikuti pembelajaran dengan model pembelajaran Resik lebih baik daripada kemampuan koneksi matematis siswa yang mengikuti pembelajaran konvensional. Jadi, model pembelajaran Resik efektif untuk meningkatkan kemampuan koneksi matematis siswa.
\end{abstract}

Kata kunci: kemampuan koneksi matematis, model pembelajaran Resik, SMA Negeri 1 Susut.

\begin{abstract}
This study aims to determine the effectiveness of the Resik learning model in improving the mathematical connection ability eleventh grade students of MIA SMA Negeri 1 Susut. This study is a quasi-experiment with post-test only control group design. The population is students of eleventh grade in MIA SMA Negeri 1 Susut in academic year $2018 / 2019$ which is reduced by 132 students'. The research sample was determined by cluster random sampling technique, obtained a sample of 46 students. The data of students' mathematical connection ability were collected through an essay test which was given to students at the end of the study. The data analysis using one-tailed t-test, right tail, with $5 \%$ significance level. The result showed that the score of $t_{\text {count }}=3,91147$ greater than $t_{\text {table }}=1,68023$. Which means that the mathematical connection ability of students who followed the implementation of Resik learning model is better than the mathematical connection ability of students who followed conventional learning. So, the Resik learning model is effective for improving students' mathematical connection ability.
\end{abstract}

Keywords: mathematical connection ability, Resik learning model, SMA Negeri 1 Susut. 


\section{PENDAHULUAN}

Koneksi berasal dari kata connection dalam bahasa inggris yang diartikan hubungan. Koneksi secara umum adalah suatu hubungan atau keterkaitan antara dua atau lebih objek. Dalam kaitannya dengan matematika yang disebut dengan koneksi matematika dapat diartikan sebagai keterkaitan secara internal dan eksternal. "Keterkaitan secara internal adalah keterkaitan antara konsep-konsep matematika yaitu berhubungan dengan matematika itu sendiri dan keterkaitan secara eksternal, yaitu keterkaitan antara matematika dengan kehidupan sehari-hari" (Sumarmo, 1994: 8).

Membuat koneksi merupakan cara untuk menciptakan pemahaman mengenai suatu objek dan sebaliknya memahami suatu objek berarti membuat koneksi. Apabila siswa mampu mengkaitkan ide-ide matematis maka pemahaman matematikanya akan semakin dalam dan bertahan lama, karena siswa mampu melihat keterkaitan antar ide-ide matematis, konteks antar topik matematis, dan dengan pengalaman hidup sehari-hari (NCTM, 2000).

Oleh karenanya kemampuan koneksi matematis menjadi sangat penting dan diperlukan oleh siswa agar mereka dapat memahami, serta tidak mengalami kesulitan dalam mempelajari matematika. Mengingat pentingnya kemampuan

setiap pembelajaran matematika seharusnya memperhatikan bagaimana kemampuan koneksi matematis siswa.

Namun kenyataannya kemampuan koneksi matematis siswa masih rendah. Berdasarkan hasil penelitian Saminanto dan Kartono (2015) dalam peneletiannya menunjukkan bahwa rata-rata kemampuan koneksi matematis siswa Indonesia masih rendah (34 \%). Rata-rata skor koneksi matematis siswa hanya 34 dari skor maksimum 100. Senada dengan penelitian tersebut, penelitian yang dilakukan oleh Siregar dan Surya (2017) menyatakan bahwa persentase kemampuan koneksi matematis siswa khususnya dalam mengaitkan konsep matematika dengan kehidupan sehari-hari masih rendah, yaitu 32 dari 180 skor total. Hal ini mengindikasikan bahwa kemampuan koneksi matematis siswa belum memadai.

Masih rendahnya kemampuan koneksi matematis siswa dalam matematika merupakan indikasi bahwa tujuan yang ditentukan dalam kurikulum matematika belum tercapai secara optimal. Menurut Nurhadi (2004: 1) menyatakan bahwa "model pembelajaran yang digunakan dapat mempengaruhi kualitas proses pembelajaran". Oleh karenanya agar tujuan tersebut dapat tercapai sesuai yang diinginkan, satu diantara caranya adalah dengan melaksanakan proses pembelajaran yang berkualitas dan efektif.

Saminanto dan Kartono (2015) menyimpulkan bahwa terdapat beberapa hal yang perlu diperhatikan dan dilakukan dalam pembelajaran matematika guna meningkatkan kemampuan koneksi matematis siswa. Pembelajaran yang dilakukan merupakan konstruksi dan pengetahuan dari pengalaman siswa sendiri, mengutamakan proses aktif, pembelajaran ditanamkan dalam konteks sosial, dan memberikan prioritas untuk belajar nyata dalam konteks yang relevan atau kontekstual. Berdasarkan hal tersebut salah satu model pembelajaran yang memiliki karakteristik demikian adalah model pembelajaran Resik (Realistic Setting Cooperative).

Menurut Suradi (2008), model Resik merupakan pembelajaran realistik yang pelaksanaannya di setting secara kooperatif. Salah satu ciri dari pembelajaran matematika dengan menggunakan model Resik adalah dengan menggunakan masalah kontekstual yang diangkat sebagai masalah awal dalam proses pembelajaran.

"Pada masalah kontekstual yang diberikan, subjek sesungguhnya telah memiliki pengetahuan informal yang cukup, tetapi untuk dapat menyelesaikannya subjek perlu menerjemahkan konteks masalah ke dalam model matematika agar dapat diselesaikan menggunakan prosedur matematika formal"(Widarti, 2012: 3).

Model pembelajaran Resik memuat enam tahap pembelajaran, yaitu tahap memotivasi siswa, tahap menyajikan informasi dan melibatkan siswa memahami 
masalah kontekstual, tahap mengorganisasi siswa ke dalam kelompok belajar dan memberikan tugas kelompok, tahap membimbing kelompok bekerja dan belajar, tahap diskusi dan negosiasi, serta tahap evaluasi dan penghargaan.

Keterkaitan model pembelajaran Resik dengan koneksi matematis dapat dilihat melalui tahapan-tahapan pada model pembelajaran Resik. Tahap pertama yaitu memotivasi siswa, pada tahap ini guru berusaha membangkitkan minat dan keingintahuan siswa tentang topik yang akan diajarkan. Hal ini dilakukan dengan cara mengaitkan materi yang akan dipelajari dengan kehidupan siswa sehari-hari. Dengan demikian siswa akan lebih tertarik dalam mengikuti proses pembelajaran.

Tahap kedua menyajikan informasi dan melibatkan siswa memahami masalah kontekstual. Pada tahap ini guru memberikan masalah kontekstual sesuai dengan materi pelajaran yang sedang dipelajari siswa dan siswa dituntut untuk mampu memahami permasalahan yang disajikan. Pemahaman siswa dapat dilihat apabila siswa mampu mengidentifikasi unsur-unsur yang diketahui dan ditanyakan dalam soal, mengetahui konsep, dan prosedurnya yang akan digunakan sebagai strategi penyelesaian (Tasni \& Susanti, 2017).

"Jika dalam proses belajar matematika siswa hanya sebatas menerima atau sekadar memenuhi tuntutan pelajaran maka dampaknya adalah siswa tidak memahami ilmu yang didapatnya. Dengan ketidakpahaman tersebut maka siswa akan sulit untuk mengkoneksikan materi matematika" (Kusmanto \& Marliyana, 2014: 62).

Tahap ketiga mengorganisasi siswa ke dalam kelompok belajar dan memberikan tugas kelompok. Adanya kerjasama siswa secara kooperatif dalam kelompokkelompok kecil untuk mengerjakan aktivitas yang menjadi tugas kelompok memiliki dampak yang amat positif untuk siswa. Pada tahap ini siswa didorong untuk melakukan penyelesian tugas tanpa pengajaran langsung oleh guru. Siswa diharapkan mampu mengumpulkan informasi tentang materi yang dibahas, serta memunculkan atau menggali pengetahuan yang telah mereka miliki sebelumnya untuk menyelesaikan permasalahan yang dihadapi dalam diskusi.

Tahap keempat membimbing kelompok bekerja dan belajar, yaitu siswa mulai mendiskusikan permasalahan yang diberikan dalam LKS. Permasalahan yang digunakan dalam LKS berbentuk soal cerita dan dikaitkan dengan konteks siswa. Sehingga pada tahap ini siswa akan dituntut mampu (1) menuliskan permasalahan dalam bentuk model matematika, (2) menuliskan konsep matematika yang mendasari jawaban, dan (3) menuliskan hubungan antar objek dan konsep matematika. Ketiga hal tersebut merupakan indikator dari kemampuan koneksi matematis (Listyotami, 2011). Pada tahap ini, peran guru mengawasi dan memberikan bantuan terbatas kepada setiap kelompok. Bantuan ini dapat berupa penjelasan secukupnya, dapat pula memberikan pertanyaan yang merangsang berpikir siswa dan mengarahkan siswa untuk lebih jelas melihat masalah yang sebenarnya atau mengarahkan siswa kepada masalah yang dihadapi. Setiap anggota kelompok harus saling membantu agar materi yang dipelajari dipahami oleh semua anggota kelompoknya.

Tahap diskusi dan negosisasi, pada tahap ini siswa akan menyampaikan apa yang mereka kerjakan sehingga pada tahap ini siswa diharapkan mampu kembali menerapkan indikator-indikator yang termuat dalam koneksi matematis. Tahap terkhir adalah evaluasi dan penghargaan. Guru dapat menilai pengetahuan atau pemahaman siswa dalam menerapkan konsep baru serta dapat mengamati proses pembelajaran yang telah berlangsung.

Keefektifan penerapan model Resik dalam pembelajaran didukung dari penelitian-penelitian sebelumnya. Penelitian yang dilakukan oleh Kemala (2017), menunjukkan bahwa pemahaman konsep matematika siswa dengan menerapkan model pembelajaran Resik lebih baik daripada pemahaman konsep matematika siswa dengan pembelajaran konvensional. Pemahaman konsep dengan kemampuan koneksi matematis memiliki hubungan yang 
linier, bahwa setiap peningkatan pemahaman konsep akan diikuti dengan peningkatan kemampuan koneksi matematis (Kusmanto \& Marliyana, 2014).

Sejalan dengan penelitian tersebut Japa, Mahardhika, dan Suarjana (2013) juga menyatakan bahwa model Resik memberikan pengaruh positif terhadap kemampuan pemecahan masalah matematika siswa dibandingkan dengan pembelajaran konvensional. Proses pemecahan masalah memerlukan membangun koneksi antara tahapan pemecahan masalah, sebagai upaya untuk menemukan solusi berdasarkan pengetahuan yang dimiliki (Schoenfeld, 1982). Hal ini mengindikasikan bahwa pengalaman siswa dalam memecahkan masalah, tentunya tidak dipisahkan dari adanya koneksi matematis.

Rafiq dan Siti (2015) telah melakukan penelitian terkait pembelajaran
Resik terhadap kemampuan koneksi matematis siswa. Dengan demikian peneliti tertarik untuk mengangkat penelitian yang berjudul "Efektivitas Model Pembelajaran Resik dalam meningkatkan Kemampuan Koneksi Matematis Siswa Kelas XI MIA".

\section{METODE}

Jenis penelitian ini adalah penelitian eksperimen, dalam kategori penelitian eksperimen semu (quasi experiment). Penelitian eksperimen semu dapat dilakukan untuk melihat pengaruh yang ditimbulkan dari perlakuan berbeda yang diberikan pada masing-masing kelompok, yang mana peneliti tidak mengontrol semua variabel dan kondisi eksperimen secara ketat (Sugiyono, 2012: 114). Desain penelitian yang digunakan adalah "post test only control group design". Desain penelitian ini dapat dilihat pada Tabel 1.

Tabel 1. Desain Penelitian

\begin{tabular}{ccc}
\hline Kelompok & Perlakuan & Post-Test \\
\hline$E$ & $X$ & $Y_{1}$ \\
\hline$C$ & - & $Y_{2}$ \\
\hline \multicolumn{3}{r}{ (Dimodifikasi dari : Dantes, 2012) }
\end{tabular}

inkuiri model Alberta terhadap kemampuan koneksi matematis siswa. Penelititian tersebut menyimpulkan bahwa pembelajaran inkuiri model Alberta dapat dijadikan salah satu model pembelajaran yang dapat digunakan untuk meningkatkan kemampuan koneksi matematis siswa. Pada model Alberta menekankan keaktifan siswa, memberi kesempatan siswa untuk mengkonstruksi pemahaman mengenai suatu konsep matematika melalui suatu kegiatan penyelidikan. Namun dalam pembelajaran inkuiri model Alberta tidak menggunakan masalah kontekstual. Oleh karena itu diperlukan suatu model pembelajaran lain dalam upaya untuk meningkatkan kemampuan koneksi matematis siswa.

Berdasarkan pemaparan di atas diduga bahwa model pembelajaran Resik memiliki pengaruh terhadap kemampuan koneksi matematis, sehingga dipandang perlu melakukan penelitian yang berkaitan dengan pengaruh model pembelajaran
Keterangan:

$E$ : Kelompok eksperimen

$C$ : kelompok kontrol

$X$ : perlakuan berupa penerapan model pembelajaran Resik

$Y_{1}$ : hasil post-test kelompok eksperimen

$Y_{2}: \quad$ hasil Post-test kelompok kontrol

Populasi dalam penelitian ini adalah seluruh siswa kelas XI MIA SMA Negeri 1 Susut yang terdiri dari 6 kelas dengan total 132 siswa. Teknik pengambilan sampel dalam penelitian ini menggunakan cluster random sampling dengan sistem pengundian. Dari hasil pengundian terpilih dua kelas yakni kelas XI MIA 1 dan XI MIA 4. Sebelum diundi untuk menentukan kelas eksperimen dan kelas kontrol, terlebih dahulu dilakukan uji kesetaraan sampel dengan menganalisis nilai ulangan umum semester genap siswa menggunakan rumus uji-t.

Berdasarkan hasil analisis diperoleh bahwa tidak terdapat perbedaan 
kemampuan awal siswa kelas XI MIA 1 dan kelas XI MIA 4 SMA Negeri 1 Susut atau dapat dikatakan bahwa sampel memiliki kemampuan yang setara. Selanjutnya kedua kelas tersebut diundi untuk menentukan kelas eksperimen dan kelas kontrol. Hasil undi menunjukkan bahwa kelas XI MIA 1 sebagai kelas eksperimen yang diberikan perlakuan dengan penerapan model pembelajaran Resik dan kelas XI MIA 4 sebagai kelas kontrol yang diberikan perlakuan dengan pembelajaran konvensional. Pembelajaran konvensional yang dimaksud adalah pembelajaran langsung.

Penelitian ini melibatkan variabel bebas dan variabel terikat. Variabel bebas dalam penelitian ini adalah model pembelajaran. Adapun variabel terikat dalam penelitian ini adalah kemampuan koneksi matematis siswa.

"Instrumen penelitian adalah alat yang digunakan oleh peneliti untuk mengumpulkan data atau informasi yang relevan dengan permasalahan penelitian" (Rully \& Poppy, 2014: 112). Jenis instrumen yang digunakan dalam penelitian ini berupa tes. Data yang akan dikumpulkan pada penelitian ini adalah berupa kemampuan koneksi matematis siswa, yang dikumpulkan melalui tes tertulis yang berupa tes uraian. Adapun indikator yang menjadi acuan dalam penyekoran hasil tes kemampuan koneksi matematis siswa dapat dilihat pada rubrik penskoran pada Tabel 2.

Setelah siswa diberikan tes kemampuan koneksi matematis, selanjutnya dilakukan pengujian hipotesis yang diajukan. Terlebih dahulu, data yang diperoleh dilakukan uji prasyarat yakni uji normalitas menggunakan Kolmogorov Smirnov dan uji homogenitas varians dengan menggunakan uji- $F$. Selanjutnya, hipotesis dilakukan dengan menggunakan uji-t satu ekor (ekor kanan). Adapun rumus untuk uji-t satu ekor (ekor kanar) dalam penelitian ini adalah sebagai berikut.

$$
t_{\text {hitung }}=\frac{\overline{X_{1}}-\overline{X_{2}}}{S_{\text {gab }}^{2} \sqrt{\frac{1}{n_{1}}+\frac{1}{n_{2}}}}
$$

\section{Dengan:}

$$
\begin{aligned}
& S_{\text {gab }}^{2}=\frac{\left(n_{1}-1\right) s_{1}{ }^{2}+\left(n_{2}-1\right) s_{2}{ }^{2}}{\left(n_{1}+n_{2}-2\right)} \\
& s_{1}{ }^{2}=\frac{\sum\left(X_{i}-\bar{X}_{1}\right)^{2}}{n-1}
\end{aligned}
$$

\begin{tabular}{|c|c|}
\hline Kriteria Jawaban Siswa & Skor \\
\hline $\begin{array}{l}\text { Tidak menjawab dan hanya menyalin permasalahan pada lembar } \\
\text { jawaban atau jawaban yang diharapkan tidak relevan. }\end{array}$ & 0 \\
\hline $\begin{array}{l}\text { Menuliskan diketahui dan ditanya dengan benar, namun jawaban } \\
\text { salah. }\end{array}$ & 1 \\
\hline $\begin{array}{l}\text { Menuliskan diketahui dan ditanya dan menuliskan permasalahan } \\
\text { dalam bentuk model matematika dengan benar, namun menuliskan } \\
\text { konsep yang mendasari jawaban dan menuliskan hubungan antar } \\
\text { objek dan konsep matematika kurang tepat dan koneksinya tidak } \\
\text { jelas. }\end{array}$ & 2 \\
\hline $\begin{array}{l}\text { Menuliskan diketahui dan ditanya dengan benar, membuat } \\
\text { permasalahan dalam bentuk model matematika tapi kurang tepat, } \\
\text { menuliskan konsep yang mendasari jawaban dengan benar, dan } \\
\text { menuliskan hubungan antar objek dan konsep matematika kurang } \\
\text { tepat dan koneksinya tidak jelas. }\end{array}$ & 3 \\
\hline $\begin{array}{l}\text { Menuliskan diketahui dan ditanya, membuat permasalahan dalam } \\
\text { bentuk model matematika, menuliskan konsep yang mendasari } \\
\text { jawaban, dan menuliskan hubungan antar objek dan konsep } \\
\text { matematika dengan benar tapi koneksinya kurang jelas. }\end{array}$ & 4 \\
\hline
\end{tabular}

Tabel 2. Rubrik Penskoran Tes Kemampuan Koneksi matematis

Menuliskan diketahui dan ditanya, membuat permasalahan dalam bentuk model matematika, menuliskan konsep yang mendasari jawaban, dan menuliskan hubungan antar objek dan konsep matematika dengan benar dan koneksi jelas. 


$$
s_{2}^{2}=\frac{\sum\left(X_{i}-\bar{X}_{2}\right)^{2}}{n-1}
$$

(Sudjana, 2005).

Keterangan:

$\overline{X_{1}}$ : rata-rata skor kelompok eksperimen

$\overline{X_{2}}$ : rata-rata skor kelompok kontrol

$S_{\text {gab }}$ : varians gabungan
Rangkuman mengenai data kemampuan koneksi matematis siswa pada kedua kelompok disajikan pada Tabel 3.

Berdasarkan Tabel 3 terlihat adanya perbedaan antara kelompok kontrol dan kelompok eksperimen. Rata-rata nilai kemampuan koneksi matematis siswa kelas eksperimen lebih tinggi dibandingkan dengan rata-rata nilai kemampuan koneksi

Tabel 4. Rangkuman Hasil Uji Normalitas Data Kemampuan Koneksi Matematis Siswa

\begin{tabular}{|c|c|c|c|}
\hline Kelas & $\boldsymbol{D}_{\text {hitung }}$ & $\boldsymbol{D}_{\text {tabel }}$ & Keterangan \\
\hline Eksperimen & 0,1711 & 0,28358 & Berdistribusi normal \\
\hline Kontrol & 0,1085 & 0,28358 & Berdistribusi normal \\
\hline
\end{tabular}

$s_{1} \quad$ : varians kelompok eksperimen

$s_{2} \quad$ : varians kelompok kontrol

$n_{1}$ : banyak subyek di kelompok eksperimen

$n_{2} \quad$ : banyak subyek di kelompok control

Kriteria pengujian adalah tolak $H_{0}$ jika $t_{h i t} \geq t_{(1-\alpha)}$, dimana $t_{(1-\alpha)}$ didapat dari tabel distribusi $t$ pada taraf signifikasi $5 \%$ dengan derajat kebebasan (dk) = $\left(n_{1}+n_{2}-2\right)$.

\section{HASIL PENELITIAN}

Penelitian ini dilaksanakan di SMA Negeri 1 Susut yang meliputi delapan kali proses pembelajaran dan satu kali pertemuan untuk pelaksanaan post test. Penelitian ini melibatkan 46 orang siswa sebagai sampel yang terdistribusi ke dalam dua kelas yaitu kelas XI MIA 1 sebagai kelompok eksperimen dan XI MIA 4 sebagai kelompok kontrol.

Data nilai kemampuan koneksi matematis diperoleh dari hasil post test kelompok eksperimen dan kelompok kontrol. matematis kelas kontrol.

Sebelum melakukan pengujian hipotesis terlebih dahulu dilakukan uji prasyarat analisis yaitu uji normalitas dan uji homogenitas. Rangkuman hasil uji normalitas kelas eksperimen dan kontrol dapat dilihat pada Tabel 4 .

Berdasarkan Tabel 4, dapat dilihat bahwa $D_{\text {hitung }}$ pada kedua kelompok sampel, baik kelompok eksperimen maupun kelompok kontrol kurang dari $D_{\text {tabel }}$ pada kelompok yang bersangkutan. Dengan demikian $\mathrm{H}_{0}$ diterima dengan taraf signifikan $5 \%$, hal ini berarti data kemampuan koneksi matematis siswa berdistribusi normal.

Setelah menguji normalitas data kemudian akan diuji homogenitas terhadap varians pasangan antar kelompok eksperimen dan kontrol. Uji yang digunakan adalah uji- $F$ dengan kriteria data homogen jika $F_{\text {hitung }}<F_{\text {tabel. }}$. Adapun hasil pengujian homogenitas varians sebaran data kemampuan koneksi matematis siswa untuk kedua kelompok sampel dengan uji- $F$ diperoleh $F_{\text {hitung }}=1,66147$. Berdasarkan tabel- $F$ untuk taraf signifikansi $5 \%$, dk

Tabel 3. Rangkuman Analisis Data Kemampuan Koneksi Matematis Siswa

\begin{tabular}{|c|c|c|c|}
\hline \multirow{2}{*}{ No } & \multirow{2}{*}{ Variabel } & \multicolumn{2}{|c|}{ Nilai Kemampuan Koneksi Matematis } \\
\cline { 3 - 4 } & & Kelompok Eksperimen & Kelompok Kontrol \\
\hline 1 & $\mathrm{~N}$ & 23 & 23 \\
\hline 2 & Mean & 86,7826 & 72,3478 \\
\hline 3 & SD & 13,9836 & 10,8486 \\
\hline
\end{tabular}


pembilang $=23$ dan $\mathrm{dk}$ penyebut $=23$, diperoleh $F_{\text {tabel }}=2,04777$. Berdasarkan hal tersebut dapat dilihat bahwa $F_{\text {hitung }}<F_{\text {tabel }}$ sehingga $H_{0}$ diterima. Hal ini berarti data kemampuan koneksi matematis siswa kelompok eksperimen dan kelompok kontrol memiliki varians yang homogen.

Berdasarkan hasil uji prasyarat yang telah dilakukan, diperoleh hasil bahwa nilai kemampuan koneksi matematis siswa berdistribusi normal dan memiliki varians yang homogen sehingga pengujian hipotesis penelitian dapat dilakukan. Pengujian hipotesis dilakukan dengan menggunakan uji- $t$ satu ekor (ekor kanan) dengan taraf signifikansi 5\%. Adapun rangkuman hasil pengujian hipotesis penelitian disajikan pada Tabel 5. kelompok eksperimen pembelajaran Resik memiliki kontribusi yang besar dalam meningkatkan kemampuan koneksi matematis siswa.

Kegiatan yang menonjol pada model pembelajaran Resik yang menyebabkan adanya perbedaan kemampuan koneksi matematis siswa, karena pada model pembelajaran Resik lebih menggunakan masalah kontekstual yang diangkat dalam proses pembelajaran. Hal ini sesuai dengan penelitian yang dilakukan oleh Widayanti (2018) yang menunjukkan bahwa pembelajaran kontekstual dapat meningkatkan kemampuan koneksi matematis siswa.

Menyajikan informasi dan melibatkan siswa memahami masalah kontekstual

Tabel 5

Rangkuman Hasil Uji-t Data Kemampuan Koneksi Matematis Siswa

\begin{tabular}{|c|c|c|c|c|c|c|}
\hline Kelompok & $\mathbf{N}$ & $\mathbf{D k}$ & $\bar{X}$ & $\mathbf{S D}$ & $\boldsymbol{t}_{\text {hitung }}$ & $\boldsymbol{t}_{\text {tabel }}$ \\
\cline { 1 - 5 } Eksperimen & 23 & 44 & 86,7826 & 13,9836 & \multirow{2}{*}{3,91147} & \multirow{2}{*}{1,68023} \\
\cline { 1 - 5 } Kontrol & 23 & 44 & 72,3478 & 10,8486 & & \\
\hline
\end{tabular}

Berdasarkan hasil perhitungan pada Tabel 5, diperoleh bahwa nilai $t_{\text {hitung }}>t_{\text {tabel, }}$, sehingga $\mathrm{H}_{0}$ ditolak dengan taraf signifikansi $5 \%$. Hal ini berarti, kemampuan koneksi matematis siswa yang mengikuti pembelajaran dengan model pembelajaran Resik lebih baik daripada kemampuan koneksi matematis siswa yang mengikuti pembelajaran konvensional.

\section{PEMBAHASAN}

Hasil analisis nilai kemampuan koneksi matematis siswa terhadap kelas eksperimen dan kelas kontrol menunjukkan bahwa rata-rata nilai kemampuan koneksi matematis siswa pada kelompok eksperimen lebih tinggi daripada rata-rata nilai kemampuan koneksi matematis siswa pada kelompok kontrol. Hal ini disebabkan karena adanya perbedaan perlakuan antara kelompok eksperimen dan kelompok kontrol. Perlakuan yang dimaksud adalah adanya perbedaan kegiatan pembelajaran yang berlangsung di kelas. Perbedaan tersebut dapat dilihat dari langkah-langkah pembelajaran yang dilaksanakan. Pada merupakan langkah kedua dari model pembelajaran Resik. Pada tahap ini, siswa diberikan kesempatan untuk memahami masalah kontekstual yang disajikan. Pada masalah kontekstual yang diberikan, siswa sesungguhnya telah memiliki pengetahuan informal yang cukup, tetapi untuk dapat menyelesaikannya siswa perlu menerjemahkan konteks masalah ke dalam model matematika agar dapat diselesaikan menggunakan prosedur matematika formal (Widarti, 2012). Oleh karenanya untuk dapat memahami masalah tersebut siswa dituntut mampu menuliskan masalah yang disajikan ke dalam model matematika. Aktivitas tersebut akan melatih kemampuan koneksi matematis siswa, khususnya pada indikator menuliskan masalah yang disajikan ke dalam model matematika.

Pemahaman siswa dapat dilihat apabila siswa mengetahui konsep, dan prosedurnya yang akan digunakan sebagai strategi penyelesaian (Tasni \& Susanti, 2017). Oleh karenanya pada tahap ini siswa juga dilatih menuliskan konsep yang mendasari jawaban dari msalah yang 
disajikan. Menuliskan konsep yang mendasari jawaban merupakan salah satu indikator dari kemampuan koneksi matematis, sehingga pada tahap ini memberikan pengaruh terhadap kemampuan koneksi matematis siswa.

Selanjutnya tahap membimbing kelompok bekerja dan belajar, selama siswa bekerja kelompok, guru berusaha memfasilitasi siswa dalam menyelesaikan LKS. Lembar Kerja Siswa yang digunakan pada model pembelajaran Resik berbentuk soal cerita dan dikaitkan dengan konteks siswa. Sesuai dengan pendapat Hadi (2005) bahwa penggunaan masalah kontekstual dalam pembelajaran didasari oleh kesadaran bahwa pembelajaran yang langsung pada penyajian konsep-konsep matematika formal yang abstrak ternyata cukup sulit dan membosankan bagi siswa, karena penyajian matematika dengan cara demikian menjadikan siswa tidak dapat melihat makna dari apa yang dipelajarinya. Dengan menggunakan masalah kontekstual siswa mengalami langsung masalah tersebut, sehingga siswa bisa menafsirkan permasalahan yang dalam bentuk cerita tersebut ke dalam model matematika. Secara tidak langsung pada tahap ini siswa belajar memodelkan permasalahan kontekstual yang disajikan ke dalam model matematika.

Dengan memberikan LKS yang berisi permasalahan kontekstual, siswa lebih banyak memiliki kesempatan untuk berlatih menuliskan masalah kontekstual ke dalam bentuk model matematika, memanfaatkan hubungan antar konsep-konsep dalam matematika, sehingga mampu menuliskan konsep yang mendasari jawaban dari masalah tersebut. Selain itu siswa dapat mengenali dan menerapkan konsep matematika dalam konteks diluar matematika khususnya dalam kehidupan sehari-hari. Melalui hal tersebut maka kemampuan koneksi matematis siswa akan terlatih.

Selanjutnya pada tahap diskusi dan negosiasi, yakni siswa diberikan kesempatan untuk menyampaikan hasil diskusi kelompoknya. Dalam mempresentasikan hasil diskusi kelompok, guru memilih siswa secara acak sebagai perwakilan kelompok untuk menyampaikan hasil diskusi di depan kelas. Ketika mempresentasikan hasil diskusi, setiap kelompok memiliki hak untuk menanggapi hasil diksusi dari kelompok lain apabila terdapat perbedaan pendapat dan saling merefleksi antar kelompok. Selain itu, ketika siswa mendemonstrasikan hasil diskusi di depan kelas, secara tidak langsung siswa dituntut mampu kembali menerapkan indikator-indikator yang termuat dalam koneksi matematis. Dalam hal ini, apabila terjadi perbedaan pendapat, guru bertindak sebagai penengah dan memberikan klarifikasi atas perbedaan pendapat yang terjadi. Adanya kegiatan diskusi dapat membuat siswa saling bertukar informasi ataupun ide dengan teman-temannya yang tentunya membawa dampak positif terhadap semua siswa baik yang berkemampuan kurang maupun berkemampuan lebih.

Berbeda dengan kelompok eksperimen, pada kelompok kontrol siswa dibelajarkan dengan pembelajaran konvensional yang menerapkan pembelajaran langsung. Pembelajaran diawali dengan guru menyampaikan topik dan tujuan pembelajaran, serta mengingatkan siswa dengan materi sebelumnya yang berkaitan dengan materi yang akan dibahas melalui kegiatan tanya jawab.

Tahap

mendemonstrasikan pengetahuan dan keterampilan, pada tahap ini guru menyajikan materi pembelajaran secara terstruktur serta memberikan beberapa contoh soal beserta penyelesaiannya. Contoh soal yang diberikan pada pembelajaran konvensional berbeda dengan model pembelajaran Resik. Pada pembelajaran konvensional, contoh soal yang disajikan merupakan soal biasa (tidak kontekstual), sehingga siswa tidak perlu menuliskan permasalahan tersebut ke dalam model matematika. Hal tersebut menyebabkan siswa kurang terlatih dalam memodelkan masalah kontekstual ke dalam model matematika.

Selanjutnya tahap membimbing pelatihan, guru memberikan latihan soal kepada siswa baik secara individu maupun diskusi dengan teman sebangku. Soal yang 
dibahas pada tahap ini juga merupakan soal biasa (tidak kontekstual). Namun berupa soal rutin. Dalam mengerjakan soal rutin siswa tidak dituntut memodelkan permasalahan ke dalam model matematika dan tidak dituntut harus mampu menuliskan hubungan antar objek dan konsep matematika. Proses yang demikian membuat siswa tidak terbiasa dalam menyelesaikan soal- soal yang berkaitan dengan kehidupan sehari-hari. Hal ini menyebabkan kemampuan koneksi matematis siswa kurang.

Tahap terkahir guru menyampaikan rencana pembelajaran untuk pertemuan berikutnya. Terlihat bahwa tahapan-tahapan dalam pembelajaran konvensional, siswa kurang dilatih untuk mengerjakan soal-soal kontekstual dan siswa kurang diberikan kesempatan untuk mengkonstruksi sendiri pemahaman mereka terhadap konsep matematika yang dipelajari, sehingga kesempatan siswa untuk mengenal dan memanfaatkan hubungan antar konsep matematika menjadi belum optimal. Selain itu, siswa juga kurang diberikan kesempatan untuk melihat dan menerapkan konsep matematika dalam kehidupan sehari-hari. Hal tersebut menyebabkan perkembangan kemampuan koneksi matematis siswa pada kelompok kontrol belum optimal.

Secara umum dapat diberikan kesimpulan bahwa model pembelajaran Resik lebih baik digunakan untuk menanamkan kemampuan koneksi matematis siswa dibandingkan dengan pembelajaran konvensional. Hal tersebut juga didukung oleh hasil uji hipotesis yang menunjukkan kemampuan koneksi matematis siswa yang mengikuti pembelajaran dengan model pembelajaran Resik lebih baik daripada kemampuan koneksi matematis siswa yang mengikuti pembelajaran konvensional. Melihat kontribusi positif tersebut, diharapkan model pembelajaran Resik dapat dikembangkan dan diterapkan dalam proses pembelajaran khususnya proses pembelajaran matematika di Indonesia.

\section{SIMPULAN DAN SARAN}

Berdasarkan hasil pengujian
hipotesis pada taraf signifikansi $5 \%$

diperoleh bahwa nilai $t_{\text {hitung }}=3,91147$ lebih dari nilai $t_{\text {tabel }}=1,68023\left(t_{\text {hitung }}>t_{\text {tabel }}\right)$ serta berdasarkan pembahasan yang telah dipaparkan pada bab sebelumnya, dapat disimpulkan bahwa kemampuan koneksi matematis siswa yang mengikuti pembelajaran dengan model pembelajaran Resik lebih baik daripada kemampuan koneksi matematis siswa yang mengikuti pembelajaran konvensional. Dengan demikian model pembelajaran Resik efektif untuk meningkatkan kemampuan koneksi matematis siswa.

Adapun saran yang dapat disampaikan berdasarkan penelitian yang telah dilakukan adalah sebagai berikut.

1. Kepada praktisi pendidikan matematika, khususnya guru mata pelajaran matematika diharapkan dalam pembelajaran di kelas dapat menerapkan model pembelajaran Resik sebagai salah satu alternatif pembelajaran, mengingat model pembelajaran Resik memiliki pengaruh positif dalam pembelajaran terutama dalam meningkatkan kemampuan koneksi matematis siswa.

2. Penelitian ini dilakukan hanya sebatas untuk mengetahui pengaruh penerapan model pembelajaran Resik terhadap kemampuan koneksi matematis siswa. Bagi peneliti lain yang tertarik disarankan agar melakukan penelitian terkait pengaruh penerapan model pembelajaran ini pada aspek pembelajaran matematika lainnya untuk mengetahui pengaruh model pembelajaran Resik dalam pembelajaran matematika secara lebih mendalam.

\section{DAFTAR PUSTAKA}

Anisa, dkk. 2017. Pengaruh Penerapan Model Realistic Setting Kooperatif (Resik) Terhadap Pemahaman Konsep Matematis Siswa Kelas XI IPAIPS SMAN $1 \mathrm{Kec}$. Harau.

Dantes, I. N. 2012. Metode Penelitian. Yogyakarta: Andi. 
Japa, I. G. N dkk. 2013. Pengaruh Model Pembelajaran Resik Berbantuan LKS Terhadap Kemampuan Pemecahan Masalah Matematika Siswa Kelas V SD di Gugus V Kecamatan Gianyar. Skripsi Universitas Pendidikan Ganesha: tidak diterbitkan.

Kusmanto. 2014. Pengaruh Pemahaman Matematika terhadap Kemampuan Koneksi Matematis Siswa Kelas VII Semester Genap SMP Negeri 2 Kasokandel Kabupaten Majalengka. EduMa. Volume 3, Nomor 2.

Listyotami, M. K. 2011. Upaya Meningkatkan Kemampuan Koneksi matematis Siswa Kelas VII A SMP N 15 Yogyakarta Melalui Model Pembelajaran Learning Cycle " $5 E$ ". Skripsi FMMIA UNY: tidak diterbitkan.

NCTM. (2014). Principles to Actions: Ensuring Mathematical Success for All (Executive Summary), (Online), (http://www.nctm.org/PtA), diakses 7 Maret 2018.

Poppy, Y \& Rully I. 2014. Metodelogi Penelitian. Bandung: Refika Aditama.

Rafiq, B \& Siti F. 2015. Peningkatan Kemampuan Koneksi Matematis Siswa SMP melalui Pembelajaran Inkuiri Model Alberta. Jurnal Pengajaran MIPA UPI, Volume 20, Nomor 1 (hlm. 18-26).

Saminanto \& Kartono. 2015. Analysis of Mathematical Connection Ability in Linear Equation with One Variable Based on Connectivity Theory. International Journal of Education and Research, Volume 3, Nomor 4 (hlm. 259-270).

Siregar, N. D. dan Edy. S 2017. Analysis of Students Junior High School Mathematical Connection Ability. International Journal of Sciences:
Basic and Applied Research, Volume 33, Nomor 2 (hlm. 309-320).

Sudjana. 2005. Metoda Statistika. Cet III. Bandung: Tarsito. 2005

Sugiyono. 2012. Metode Penelitian Kuantitatif Kualitatif dan $R \& D$. Bandung: Alfabeta.

Suradi. 2008. Model Pembelajaran RESIK sebagai Strategi Mengubah Paradigma Pembelajaran Matematika di SMP yang Teachers Oriented menjadi Student Oriented. Tersedia pada: https://www.scribd.com/doc/551494 45/Suradi-Model-PembelajaranResik-Sebagai-Strategi. (diakses tanggal 15 Maret 2018).

Sumarmo, U. 1994. Suatu Alternatif Pengajaran untuk Meningkatkan Kemampuan Komunikasi matematika pada Guru dan Siswa SMP. Laporan penelitian IKIP Bandung.

Suwiasa, I Wayan. 2014. Pengaruh Pendekatan Reciprocal Teaching Terhadap Kemampuan Koneksi Matematis Siswa Kelas X MIA SMA Negeri 8 Denpasar. Skripsi Jurusan Pendidikan Matematika Undiksha: tidak diterbitkan.

Tasni dan Susanti. 2017. Membangun Koneksi Matematis Siswa dalam Pemecahan Masalah Verbal. Jurnal tadris mtematika. Volume 10 , Nomor 1( hlm. 103-116).

Widarti, A. 2012. Kemampuan Koneksi Matematis dalam Menyelesaikan Masalah Kontekstual ditinjau dari Kemampuan Matematis Siswa. Tersedia pada: www.academia.edu (diakses tanggal 20 maret 2018). 